\title{
Dr. Louis Kristal at 100: witness to the evolution of surgery in Canada
}

The views expressed in this editorial are those of the author and do not necessarily reflect the position of the Canadian Medical Association or its subsidiaries.

T he lecture, though impromptu, was to be special, but maybe not as special as the medical school realized. Canadian Nobel Prize winner, Major Sir Frederick Banting was on his way to Britain when he took the opportunity to speak to Dalhousie University medical students. Banting had wished to pursue a career in orthopedic surgery, having worked with Professor Clarence Starr at the Canadian Orthopedic Hospital, Ramsgate, during the First World War and in the Hospital for Sick Children, Toronto, Ont., after that. Banting switched to a career in research following the stunning success of his insulin project, which he undertook during a lull in his clinical practice. He became the founding head of the government-funded Banting and Best Research Institute at the University of Toronto. By 1938 Banting had turned his attention to aviation medicine as head of the Royal Canadian Air Force's Number 1 Clinical Investigation Unit. A week after the Dalhousie lecture, on Feb. 21, 1941, Banting died when the plane that was taking him to Britain crashed close to Musgrave Harbour, Nfld. Dr. Louis Kristal (Dalhousie, 1943), who celebrates his 100th birthday, remembers Banting's last lecture well. Banting dispensed with platitudes about honour and service even though he had won the Military Cross for gallantry in the previous war and instead explained the physiology of flying to the class and demonstrated the new anti-gravity suit designed by Wilbur Franks in his research unit.

Kristal had planned to enlist upon graduation, but that plan was delayed because he had appendicitis. Upon recovery, he was recalled to his home town of New Waterford, NS, by Dr. David Hartigan. Hartigan, who had been the local member of parliament and had served in the McKenzie King government, used his connections to have Kristal's job, colliery doctor, declared essential to the war effort, curtailing all further attempts at enlistment. Instead, Hartigan taught Kristal surgery.

In 1944, Richard Goldbloom, the overachieving medical student son of McGill University's professor of pediatrics, met Ruth Schwartz and his destiny, which lay not in Montreal but in New Waterford, Schwartz's home town. In pursuit of her, Goldbloom arranged an elective with the town's medical practice, which provided comprehensive medical care to miners and their families under an insurance scheme known colloquially as the "Check-Off." ${ }^{1}$ Goldbloom describes Kristal as his "principal mentor" and the town's "most competent surgeon."2 Kristal's practice included general surgery (appendectomy, perforated peptic ulcers), orthopedics (closed reduction of fractures and amputations), gynecology (curettage, hysterectomy, cesarean section) and surgical treatments of tuberculosis (pneumothorax) and diphtheria (tracheotomy). Goldbloom recalls the locals calling Kristal the "head cutter," recognizing not only his superior surgical skills, but also his willingness to undertake burr holes to drain epidural hematomas. Anesthesia was provided by another general practitioner (GP) specialist trained on the job, Dr. Joe Roach.

Goldbloom married Schwarz, and they settled in Halifax, where together they had a remarkable effect on the medical community, the Province and Canada. Kristal married Hartigan's daughter Carmel, who was Schwarz's best friend. In 1953, the Kristals went to Montreal for a year so that he could upgrade his surgical training at the Royal Victoria Hospital. One of his anecdotes from this period concerns the care of Dr. Wilder Penfield, who Kristal admitted to hospital for a relatively minor operation. In doing so, Kristal undertook the traditional history and physical examination, including a complete assessment of the nervous system. Penfield was kind, complimenting Kristal on his thoroughness. Unlike Dr. Gerald LeBrun, a leading GP surgeon in Halifax, Kristal did not take the certification examination of the Royal College. ${ }^{3}$ The Kristals returned to Cape Breton, where he continued as a GP surgeon for another decade until Medicare spelled the end of the Check-Off system and access to Royal College-certified surgeons the end of GP surgery. ${ }^{4}$ Interestingly, the Acts to provide universal public medicare in Canada were guided through parliament by the Kristals' good friend, the late Allan MacEachen, who acknowledged that his personal experience of the CheckOff system motivated his desire for Medicare. ${ }^{5}$

After more than 20 years in an unrelenting high-stakes practice in New Waterford, Kristal moved to become a family physician in Brantford, Ont. Interestingly, he was quickly persuaded by his new colleagues to undertake anesthesia training in St. Joseph's Hospital, Toronto, in order to supplement the Brantford hospital's anesthesia staff, which Kristal did for another decade until Royal 
College-certified anesthesiologists were available there. Finally, in 1974 Kristal was able to concentrate on family medicine, becoming a much-loved physician who inspired many in the local community to choose medicine as a career. Kristal closed his practice 40 years after graduating, but he continued as a surgical assistant and mentor until age 78 .

Roach continued his remarkable career in New Waterford long into old age. ${ }^{6}$ Goldbloom, the gentleman leader of pediatrics in Canada, continues to inspire new generations of physicians in Halifax. LeBrun became the doyen of the Dalhousie medical faculty. ${ }^{3}$ Kristal recalled for me the immense satisfaction he felt when he noticed the tracheotomy scar on a man of whom he was asking directions during a visit home. It was more than 30 years since he had saved the man, who was then a child, from diphtheria.

With this editorial, the Canadian fournal of Surgery pays tribute to these remarkable doctors. The journal recognizes the life and career of Kristal, who is a witness to the evolution of surgical specialties from general practice in Canada. We wish the Kristals happiness and good health in retirement, as they continue to inspire all who encounter them.

\section{Vivian McAlister, MB}

Coeditor, Canadian Fournal of Surgery

Acknowledgements: Information for this article was kindly provided to the author by Dr Louis Kristal, his wife Carmel Kristal and their daughter, Carrie Kristal-Schroder.

Competing interests: None declared.

DOI: $10.1503 /$ cjs.015817

\section{References}

1. McAlister C, Twohig P. The Check-Off: a precursor of medicare in Canada? CMA7 2005; 173:1504-6.

2. Goldbloom RM. A Lucky Life. Halifax (NS): Formac Publishing Company Limited; 2013.

3. Grant D. Man of medicine. Halifax Magazine. 2016 Apr. 7. Available: http://halifaxmag.com/bedford-magazine/man-of-medicine/ (accessed 2017 Oct. 18).

4. McAlister C. Interview with Dr. A. S. MacDonald, Halifax, NS. The Cape Breton Coal Miners' Check-Off System of Healthcare Insurance. CBC Radio; 2003. Available: http://hdl.handle.net/10222/37719 (accessed 2017 Oct. 18).

5. McAlister C. Interview with Allan MacEachen. The Cape Breton Coal Miners' Check-Off System of Healthcare Insurance. CBC Radio; 2003. Available: http://hdl.handle.net/10222/37723 (accessed 2017 Oct. 18).

6. McAlister C. The old country doctor. CMA7 2013;185:985-6.

\section{Le $\mathrm{D}^{r}$ Louis Kristal à 100 ans : témoin de l'évolution de la chirurgie au Canada}

Les opinions exprimées dans cet éditorial sont celles de l'auteur et ne représentent pas nécessairement celles de l'Association médicale canadienne ou ses filiales.

a conférence, bien qu'impromptue, s'annonçait déjà spéciale, mais elle a dépassé de loin les attentes de la faculté de médecine. Le major sir Frederick Banting, lauréat canadien du prix Nobel, en route pour la GrandeBretagne, a profité de son passage pour s'adresser aux étudiants en médecine de l'Université Dalhousie. Après avoir travaillé avec le professeur Clarence Starr à l'Hôpital canadien d'orthopédie à Ramsgate, en Angleterre, durant la Première Guerre mondiale, et ensuite à l'Hôpital pour enfants de Toronto, en Ontario, Banting se voyait faire carrière en chirurgie orthopédique. Pourtant, il s'est plutôt consacré à la recherche en raison de la brillante réussite de son projet sur l'insuline, qu'il avait entrepris à la suite d'un ralentissement de sa pratique clinique, et est devenu directeur fondateur de l'Institut Banting and Best, établissement financé par l'État, à l'Université de Toronto. En 1938, Frederick Banting a réorienté sa carrière vers la médecine aéronautique, prenant la tête de la principale unité de recherche clinique de l'Aviation royale canadienne. Le 21 février 1941, 1 semaine après sa conférence à l'Université Dalhousie, Frederick Banting est décédé près de Musgrave Harbour, à Terre-Neuve, dans l'écrasement de l'avion qui devait le mener en Grande-Bretagne. Le Dr Louis Kristal (Dalhousie, 1943), qui célèbre cette année son $100^{\mathrm{e}}$ anniversaire, se souvient bien de la dernière conférence de Banting. Loin de s'empêtrer dans les platitudes sur l'honneur et le service, malgré la Croix militaire qu'il a reçue pour sa bravoure pendant la guerre, il s'est plutôt concentré sur l'influence du transport aérien sur la physiologie et la démonstration de la nouvelle combinaison de vol anti-gravité conçue par Wilbur Franks dans son unité de recherche.

Le $\mathrm{D}^{\mathrm{r}}$ Kristal avait prévu s'enrôler à la fin de ses études, mais n'a pu le faire en raison d'une appendicite. Une fois rétabli, il a été rappelé à sa ville natale de New Waterford, en Nouvelle-Écosse, par le D ${ }^{r}$ David Hartigan. Ce dernier, député local qui avait fait partie du gouvernement de MacKenzie King, s'était servi de ses contacts pour que l'emploi de médecin minier du $\mathrm{D}^{\mathrm{r}}$ Kristal soit déclaré essentiel à l'effort de guerre, prévenant ainsi toute nouvelle tentative d'enrôlement. Le $\mathrm{D}^{\mathrm{r}}$ Hartigan en a profité pour enseigner la chirurgie au $\mathrm{D}^{\mathrm{r}}$ Kristal.

En 1944, Richard Goldbloom, fils d'un professeur de pédiatrie à l'Université McGill, à Montréal, et brillant étudiant en médecine, a rencontré Ruth Schwartz et a scellé 